http://jmscr.igmpublication.org/home/

ISSN (e)-2347-176x ISSN (p) 2455-0450

crossref DOI: https://dx.doi.org/10.18535/jmscr/v8i5.72

Journal Of Medical Science And Clinical Research

IGM Publication

An Official Publication of IGM Publication

\title{
To study the prevalence of Retinopathy complication in newly diagnosed Type 2 Diabetes Mellitus
}

\author{
Authors \\ Dr Kaushal Kumar Sinha ${ }^{1}$, Dr Nistha Kishore ${ }^{2}$ \\ ${ }^{1}$ Fellow- Non Invasive Cardiology, GIPMER \\ ${ }^{2}$ St Stephens Hospital
}

\section{Introduction}

Diabetes Mellitus (D.M.) refers to a group of common metabolic disorders that share the phenotype of hyperglycemia ${ }^{1}$. It results from a defect in insulin secretion and/or insulin action, which results in hyperglycaemia with disturbances of carbohydrate, fat and protein metabolism ${ }^{2}$.

Diabetes is one of the commonest chronic non communicable diseases affecting the society at large both in developing and developed countries. It is generally classified as type 1, type 2 or other specific types $^{3}$.

Type 1 diabetes is generally considered a $\mathrm{T}$ cell mediated autoimmune disease involving destruction of the insulin secreting $\beta$ cells in the pancreas, resulting in absolute insulin deficiency, whereas type 2 diabetes is characterised by resistance to the action of insulin and an inability to produce sufficient insulin to overcome this 'insulin resistance, 4 .

Globally, all types of diabetes are on the increase, type 2 diabetes in particular ${ }^{5}$. While diabetes has been known for many centuries, the prevalence has reached epidemic level proportion only recently ${ }^{6}$. The rise of prevalence has been more alarming in developing countries than in developed countries. There has also been a trend towards a shift in the mean age of onset of type 2 diabetes to a much younger age ${ }^{7}$.

As per the $9^{\text {th }}$ edition of International Diabetes Federation Atlas, 2019,. The global diabetes prevalence is estimated to be $9.3 \%$ (463 million people), rising to $10.2 \%$ (578 million) by 2030 and $10.9 \%$ (700 million) by $2045 \ldots$ The major proportion of this increase will occur in developing countries of the world like India ${ }^{8}$. One in two $(50.1 \%)$ people living with diabetes do not know that they have diabetes.

India leads the world with largest number of diabetic subjects earning the dubious distinction of being termed the "Diabetes Capital of the World.

Type 2 diabetes is accompanied by a high prevalence of associated disorders like the various components of the metabolic syndrome like hypertension, dyslipidemia and obesity; micro vascular complications like retinopathy (Rt), nephropathy $(\mathrm{Np})$, neuropathy $(\mathrm{Nu})$ and macro vascular complications like coronary artery disease, peripheral vascular disease and cerebrovascular disease resulting in significantly high morbidity and mortality ${ }^{[9-14]}$. The chronic complications of diabetes mellitus translate into a significant economic burden on individuals and community at large $\mathrm{e}^{14}$. 
Due to its asymptomatic course, type 2 diabetes evades diagnosis for many years. Harris et al. ${ }^{15}$ estimated a gap of 9 to 12 years between the onset of type 2 diabetes and its clinical diagnosis. Long standing diabetes mellitus is associated with an increased prevalence of microvascular and macrovascular complications. The first indication of the presence of type 2 diabetes mellitus may actually be detected at the time of diagnosis of a diabetic complication.

\section{Aims and Objectives}

To study the Prevalence of retinopathy complication in newly diagnosed type 2 diabetes mellitus.

\section{Materials and Methods}

In this study, 100 newly diagnosed cases of type 2 diabetes mellitus patients were evaluated. A cross section of both male and female diabetes patients diagnosed within the last 3 months ( new onset) attending the general medicine indoor and outpatient department and other clinical departments of katihar medical college, katihar was taken into study.

A detailed history, clinical examination and relevant investigations were performed.

\section{History}

Age, sex and duration of diabetes were recorded. Family history of diabetes and personal medical history was enquired. History of symptoms suggestive of retinopathy complication like blurred vision, fluctuating vision, impaired colour vision, dark or empty area in vision, floaters in vision, vision loss were taken

\section{Inclusion Criteria}

Patients with

- Newly diagnosed case of type 2 diabetes mellitus

- Cases within 3 months of diagnosis

\section{Exclusion Criteria}

Patients with:
- Diagnosed type 2 diabetes of more than 3 months duration

- Previous history of any vascular disease

- End stage renal disease

- Pre existing neurological disease including stroke, dementia

- History of nephrotoxic, neurotoxic or oculotoxic drug use

Ophthalmoscopic examination included a detailed dilated fundus examination done by indirect ophthalmoscopy.

Non-proliferative diabetic retinopathy (NPDR) was diagnosed by the presence of microaneurysms, blot haemorrhages or cotton wool spots. Proliferative diabetic retinopathy (PDR) was defined as the presence of abnormal new vessels on the disc or elsewhere.

\section{Biochemical Analysis}

Biochemical analysis of the following were done in the department of Biochemistry

\section{American Diabetes Association Guidelines 2019 (ADA 2019)}

- Fasting and/or $2 \mathrm{hr}$ post 75 oral anhydrous glucose plasma glucose level was estimated by enzymatic glucose oxidation method. A basal FPG> $126 \mathrm{mg} / \mathrm{dl}$, and a plasma glucose $>200 \mathrm{mg} / \mathrm{dl}$ at $2 \mathrm{hr}$ post 75 glucose confirmed on a second occasion was diagnostic of diabetes.

- Glycosylated haemoglobin (HbA1c) was estimated by ion exchange chromatography. In diabetes mellitus the value is $\geq 6.5$. It gives an idea of the plasma glucose control on the preceding 3 months.

\section{Result and Analysis}

Table No.1 Sex Wise Distribution of Population

\begin{tabular}{|c|c|c|}
\hline SEX & NUMBER & \%AGE \\
\hline MALE & 60 & 60 \\
\hline FEMALE & 40 & 40 \\
\hline
\end{tabular}

In our study $60 \%$ were male and $40 \%$ were female

- Type 1 diabetes mellitus 
Table No. 2 Distribution of Population in Different Age Group

\begin{tabular}{|c|c|c|}
\hline $\begin{array}{c}\text { Age Groups } \\
\text { (in yrs) }\end{array}$ & Number & \% Age \\
\hline $36-45$ & 14 & 14 \\
\hline $46-55$ & 51 & 51 \\
\hline $56-65$ & 35 & 35 \\
\hline
\end{tabular}

Majority of cases were in the age group of 46-55 years, followed by in age group 56-65 years.

Table No. 3 Showing the Prevalence of Retinopathy in Population

\begin{tabular}{|c|c|c|}
\hline Complication & $\begin{array}{c}\text { Number } \\
(\mathbf{N = 1 0 0})\end{array}$ & Percentage \\
\hline ABSENT & 93 & 93 \\
\hline PRESENT & 7 & 7 \\
\hline
\end{tabular}

$7 \%$ of population were having retinopathy complication at the time of diagnosis

Table No. 4 Showing Prevalence of Retinopathy in Different Age Groups

\begin{tabular}{|c|c|c|c|}
\hline $\begin{array}{c}\text { AGE GROUPS } \\
\text { (in yrs) }\end{array}$ & NPDR & PDR & \% AGE \\
\hline $\begin{array}{c}36-45 \\
(\mathrm{~N}=14)\end{array}$ & 1 & 0 & 7.14 \\
\hline $\begin{array}{c}46-55 \\
(\mathrm{~N}=51)\end{array}$ & 1 & 0 & 1.96 \\
\hline $\begin{array}{c}56-65 \\
(\mathrm{~N}=35)\end{array}$ & 3 & 2 & 14.28 \\
\hline
\end{tabular}

NPDR- non proliferative diabetes retinopathy

PDR- proliferative diabetes retinopathy

Highest prevalence was seen in 56-65 age groups

Table No. 5 Showing Distributions of Retinopathy in Male and Female

\begin{tabular}{|c|c|c|c|}
\hline SEX & NPDR & PDR & $\%$ \\
\hline $\begin{array}{c}\text { MALE } \\
(\mathrm{N}=60)\end{array}$ & 2 & 1 & 5 \\
\hline $\begin{array}{c}\text { FEMALE } \\
(\mathrm{N}=40)\end{array}$ & 3 & 1 & 10 \\
\hline
\end{tabular}

Retinopathy was present in $10 \%$ of female and $5 \%$ of male

\section{Discussion}

The present cross sectional study was carried out on 100 consecutive patients of type 2 diabetes who were diagnosed recently (duration less than 3 months). The mean age at diagnosis was found to be 53.7 years. This signifies that in our hospital, diabetic patients are presenting late. Among the newly diagnosed patients 60 were male and 40 patients were female.

Age wise analysis of the patients reveals that most of the patient were in age group 46-55 yrs $n=51$ $(51 \%)$, followed by in age group $56-65 \mathrm{n}=35$ $(35 \%)$ and least number in $35-45 \mathrm{n}=14(14 \%)$. This corroborates with the work done by RAMACHANDRA et al ${ }^{16}$ which shows that in developing countries, the majority of diabetes patients are in the age range of 45-64 years whereas in the developed countries are aged $>65$ years. In our study $86 \%$ of population was in age group $46-65 y$ rs.

Diabetic retinopathy is seen in $7(7 \%)$ patients .The result concurs with the study done by REEMA et al. ${ }^{17}$, PREMLATHA et al. ${ }^{18}$,CURES STUDY $^{19}$ and recently published multicentre observational study from India conducted by SOSALE et al. ${ }^{20}$ who reported a prevalence of $6.1 \%$ but are lower than most of the studies from the western world ${ }^{21,22,23}$. It is difficult to identify the reasons for such variation in prevalence rates among various populations but ethnic susceptibility, age, healthcare facilities and other risk factors could have contributed to the differences. Retinopathy was seen in $5 \%$ of male and $10 \%$ of female but this was statistically not significant. The mean age of patients having retinopathy was higher than those without it (56.71yrs vs. $53.49 \mathrm{yrs}$ ) but this was statistically not significant.

\section{Summary and Conclusion}

The study was carried out with the intent to assess the prevalence of diabetic complications of retinopathy in the newly diagnosed type 2 diabetics. Prevalence of complications is high even at the time of diagnosis of Type 2 diabetes. This is probably because of the insidious onset of diabetes and long duration of asymptomatic disease before symptoms develop. Hence screening tests for complications are strongly recommended at the time of diagnosis not only for early detection, but also to prevent the progression into end stage disease. 
Endeavour should be made to control hyperglycemia and hypertension tightly by appropriate therapeutic measures so that the occurrence and worsening of complications could be mitigated.

There is an urgent need for concerted efforts by Government and Non-governmental sectors to implement national programmes aimed at prevention, management and surveillance of the disease.

\section{References}

1. Harrison's principles of Internal Medicine, $20^{\text {th }}$ edition 2018. P- 2850.

2. Hovens MMC, Van de loar FA et al. Acetylsalicyclic acid (aspirin) for primary prevention of cardiovascular disease in type 2 diabetes (protocol) Cochrane database os systematic reviews 2005, issue 3. Art no. CD005446.

3. Mohan V, Pradeepa R \& Anjana R M , Diabetes in India- An Epidemiological review. Current Controversies and Consensus in Diabetes Management, $1^{\text {st }}$ edition 2015. P- 1.

4. Davidson's principles \& practice of Medicine, $23^{\text {rd }}$ edition, 2018. P -728.

5. International Diabetes Federation - IDF Diabetes Atlas, $6^{\text {th }}$ edn. Brussels, Belgium : International Diabetes Federation, 2013

6. Major RM. A history of medicine. Blackwell, oxford, 1954; P- 67

7. Progress in Medicine Vol. XXIX 2015. P164

8. International Diabetes Federation. The Diabetes Atlas, $9^{\text {th }}$ ed. 2019.

9. MJ Garcia, PM McNamara, T Gordon, WB Kannel. Diabetes, 1974, 23, 105-111

10. WB Kannel, DL McGee. Circulation, 1979, 59, 8-13.

11. J Stamler, D Wentworth, J Neaton, JA Schoenberger, D Feigal; for the MRFIT Research Group. Circulation, 1984, 70, 11161.
12. SM Haffner; S Lehto; T Ronemaa; K Pyorala; M Laasko. N Engl J Med, 1998, 339, 229-234.

13. A Juutilainen; S Lehto; T Ronnemaa; K Pyorala; M Laakso. Diabetes Care, 2008, 31, 714-719.

14. O Wirta; A Pasternak; J Mustonen; P Laippala; Y Lahde. Clin Nephrol, 1999, 51, 329-334.

15. Harris MI, Klein R, Welborn TA, Knuiman MW. Onset of NIDDM ocurrs at least 4-7 yr before clinical diagnosis. Diabetes Care 1992; 13:815 - 819.

16. Ramachandran A. Socioeconomic burden of diabetes in India. Suppl. JAPI 2007; 55:9

17. Rema M, Deepa R, Mohan V: Prevalence of retinopathy at diagnosis among type 2 Diabetic patients attending a diabetic centre in south India. $\mathrm{Br} \mathrm{J}$ Ophthalmol 2000; 84: 1058 -1060.

18. Premlata G, Rema M, Mohan V complications of diabetes mellitus at diagnosis in south indian type 2 diabetic patients int. j. diab. dev. countries (1998), vol. 18:58-63

19. Rema M, Premkumar S, Anitha B, Deepa R, Pradeepa R, Mohan V. Prevalence of diabetic retinopathy in urban India: the Chennai Urban Rural Epidemiology Study (CURES) eye study, I. Invest Ophthalmol Vis Sci 2005; $46: 2328-33$.

20. A . Sosale, K M P Kumar, S M Sadikot et al., "Chronic complications in newly diagnosed patients with type 2 diabetes mellitus in India", Indian Journal of Endocrinology and Metabolism, vol. 18, no. 3, pp. 355-360, 2014.

21. Owens DR, Volund A, Jones D, Shannon AG, Jones IR, Birtwell AJ, Luzio S, Williams S, Dolben J, Creagh FN: Retinopathy in newly presenting noninsulin-dependent (type 2) Diabetic patients. Diabetes Res 1988; 9: 59-65. 
22. Tzeng TF, Hsiao PJ, Hsieh MC, Shin SJ: Association of nephropathy and Retinopathy, blood pressure, age in newly diagnosed type 2diabetes mellitus. Kaohsiung J Med Sci 2001; 17: 294-301.

23. Kohner EM, Aldington SJ, Stratton IM, Manley SE, Holman RR, Matthews DR, Turner RC: United Kingdom Prospective Diabetes Study, 30: diabetic retinopathy at diagnosis of non-insulin-dependent diabetes mellitus and associated risk factors. Arch Ophthalmol 1998; 116: 297303. 